\title{
Analisis Pengaruh Strategi Bauran Pemasaran Jasa (3P)Terhadap Keputusan Mahasiswa Memilih STIM SUKMA Medan
}

\author{
Yuni Asri Ningratri \\ STIM Sukma Medan \\ J1. Sakti Lubis No. 80 \\ Medan, Sumatera Utara
}

\begin{abstract}
Abstrak - Keputusan mahasiswa memilih perguruan tinggi berhubungan dengan suatu strategi ataupun kebijakan dalam bauran pemasaran jasa (3P) yang terdiri dari : orang (people), bukti fisik (Physical evidence) dan proses (process). Penelitian ini bertujuan untuk : menganalisis dan membuktikan pengaruh antara strategi bauran pemasaran jasa (3P) yang terdiri dari : orang (people), bukti fisik (Physical evidence), dan proses baik secara parsial maupun secara simultan dengan keputusan mahasiswa memilih STIM Sukma Medan. Teori yang digunakan dalam penelitian ini adalah teori tentang strategi bauran pemasaran jasa, teori perilaku konsumen dan keputusan pembelian konsumen. Teknik pengumpulan data dengan kuesoiner dan didukung dengan wawancara. Jumlah sampel penelitin ini adalah sebanyak 149 mahasiswa dan penarikan sampel digunakan teknik Nonprobability Sampling dengan pendekatan sampling jenuh. Metode analisis regresi untuk menguji hipotesis digunakan uji t dan uji $\mathrm{F}$ pada tingkat kepercayaan $95 \%, \alpha=0,05 \%$. Hasil penelitian menunjukkan bahwa secara parsial (uji t) variabel orang, bukti fisik dan proses memiliki hubungan positif yang tidak signifikan dengan keputusan mahasiswa memilih STIM Sukma Medan. Dan secara simultan (bersama-sama/uji F) hubungan seluruh variabel bebas berupa bauran pemasaran jasa dengan variabel terikat adalah signifikan (nyata).
\end{abstract}

Kata Kunci : Jasa, Bauran Pemasaran Jasa dan Keputusan Memilih.

\section{PENDAHULUAN}

\section{Latar Belakang}

Pendidikan merupakan bentuk dari investasi jangka panjang (long-term investment) artinya bahwa investasi pada bidang sumber daya manusia memang tidak segera bisa dinikmati hasilnya. Perguruan Tinggi merupakan salah satu bagian penting dalam dunia pendidikan yang ikut bertanggungjawab dalam upaya mencerdaskan kehidupan bangsa. Dominasi perguruan tinggi swasta berupa sekolah tinggi juga terjadi di Kota Medan, banyaknya jumlah perguruan tinggi swasta berbentuk sekolah tinggi menimbulkan persaingan yang semakin atraktif (Wijaya, 2012).

Oleh karena itu penting merumuskan strategi pemasaran jasa pendidikan yang optimal agar dapat memenangkan persaingan antar pendidikan tinggi dan untuk meningkatkan akselerasi peningkatan kualitas serta profesionalisme manajemen pendidikan tinggi (Margaretha dan Nilo, 2016), yakni dengan memahami sikap dan faktor-faktor yang menjadi pertimbangan calon mahasiswa memilih perguruan tinggi swasta melalui konsep marketing mix (Suparto, 2014).

Penurunan jumlah mahasiswa baru untuk beberapa bahwa tahun dapat menjadi indikasi bahwa STIM Sukma Medan harus berusaha untuk lebih memfokuskan strategi pemasarannya pada hal-hal yang diinginkan mahasiswa sebagai target pasarnya. Strategi bauran jasa ini sangat menentukan keputusan mahasiswa memilih suatu perguruan tinggi.

Berdasarkan pada fenomena di atas, penelitian ini bertujuan : untuk mengetahui faktor-faktor penting yang mempengaruhi keputusan mahasiswa memilih STIM SUKMA Medan sebagai tempat melanjutkan pendidikan dengan menggunakan metode analisis strategi bauran pemasaran 3P (people,process, physical evidence).

\section{LANDASAN TEORI}

\subsection{Pengertian Jasa}

Zeithaml dan Bitner dalam Hurriyati (2009:28) : "Jasa pada dasarnya adalah seluruh 
aktivitas ekonomi dengan output selain produk dalam pengertian fisik, dikonsumsi dan diproduksi pada saat bersamaan, memberikan nilai tambah dan secara prinsip tidak berwujud (intangible) bagi pembeli pertamanya".

Menurut Rambat Lupiyoadi (2009) Jasa Pendidikan Tinggi memiliki karakteristik : 1) Jasa murni (pure services). 2) Diberikannya membutuhkan pengguna jasa.3) Penerima Jasa adalah orang. 4) Hubungan pelanggan berdasarkan hubungan keanggotaan (member relationship).

\subsection{Pengertian Strategi Bauran Pemasaran Jasa}

Dalam manajemen pemasaran dikelompokkan dalam tiga aspek yang sering dikenal dengan marketing mix atau bauran pemasaran jasa (3P). Marketing mix jasa pendidikan adalah elemen-elemen organisasi perusahaan yang dapat dikontrol oleh perusahaan dalam melakukan komunikasi dengan peserta didik dan akan dipakai untuk memuaskan peserta didik (Hurriyati, 2009).

Lalu menurut Buchari Alma (2007) marketing mix merupakan strategi mencampur kegiatan-kegiatan maksimal, agar dicari kombinasi maksimal sehingga mendatangkan hasil yang paling memuaskan. Menurut Hurriyati (2009) untuk pemasaran jasa perlu bauran pemasaran jasa yang diperluas (expanded marketing for services) dengan penambahan unsur non-traditional marketing mix, yaitu people (orang), physical evidence (kondisi fisik) dan process (proses).

Bauran pemasaran jasa terdiri dari tiga kelompok variabel yang disebut "tiga P", yaitu

\section{People/Orang}

People yang berfungsi sebagai service provider sangat mempengaruhi kualitas jasa yang akan diberikan. Menurut Hurriyati (2009) pada perguruan tinggi, sumber daya manusia meliputi administrator, dosen dan pegawai. Mereka perlu memiliki kompetensi yang tinggi karena mereka secara langsung menyampaikan jasa kepada para mahasiswa sehingga tingkat puas atau tidaknya mahasiswa tergantung dari cara penyampaian jasa yang dilakukannya.

2. Physical Evidence/Bukti fisik

Unsur-unsur yang termasuk dalam sarana fisik antara lain, lingkungan fisik yang meliputi bangunan fisik, peralatan, perlengkapan, logo, warna dan barangbarang lainnya yang disatukan dengan pelayanan.

Yazid (2008:20) menyatakan bahwa "dalam sejumlah kasus, bukti ini mencakup fasilitas fisik dimana jasa ditawarkan, seperti fasilitas kantor dan peralatan perusahaan yang ada".

\section{Process/Proses}

Lupiyoadi dan Hamdani (2008) mendefenisikan proses sebagai gabungan semua aktivitas, umumnya terdiri atas prosedur, jadwal pekerjaan, mekanisme, aktivitas dan hal-hal rutin, dimana jasa dihasilkan dan disampaikan kepada konsumen. Dalam hal jasa pendidikan tinggi, sesuai dengan penelitian pada Perguruan Tinggi yang dimaksud dengan proses adalah serangkaian kegiatan yang dialami mahasiswa selama dalam pendidikannya, misalnya diawali dari prosedur penerimaan mahasiswa baru, jadwal testing, daftar ulang proses belajar mengajar, proses bimbingan skripsi, proses ujian, proses wisuda dan sebagainya.

\subsection{Keputusan Pembelian}

Buchari Alma (2007) menyatakan keputusan pembelian adalah suatu keputusan yang dilakukan oleh konsumen yang dipengaruhi oleh kebudayaan, kelas sosial, keluarga dan referensi grup yang akan membentuk suatu sikap pada diri individu kemudian melakukan pembelian. keputusan pembelian merupakan suatu proses dimana mahasiswa memilih untuk menggunakan produk atau jasa dari berbagai alternatif 
pilihan yang diberikan oleh perguruan tinggi sebagai penyedia barang atau jasa pendidikan. Maka jasa perguruan tinggi harus berusaha memahami perilaku mahasiswa terutama dalam melakukan pengambilan keputusan.

\section{METODOLOGI PENELITIAN}

Penelitian ini dilakukan dengan menggunakan pendekatan survey, yang merupakan kegiatan mengumpulkan data sebanyak-banyaknya mengenai fakta-fakta yang merupakan pendukung terhadap penelitian, dengan maksud untuk mengetahui status, gejala serta menentukan status dengan cara membandingkan dengan standard yang sudah dipilih dan atau ditentukan (Arikunto, 2009).

Dalam penelitian ini yang menjadi populasi adalah seluruh mahasiswa S-1 STIM Sukma Medan Tahun Ajaran 2012/2013 yang berjumlah 149 orang. Teknik pengambilan sampel pada penelitian ini adalah menggunakan teknik Nonprobability Sampling dengan pendekatan sampling jenuh. Sampling jenuh merupakan metode pengambilan sampel yang mengambil semua anggota populasi menjadi sampel (Hidayat, 2008). Pengujian dilakukan dengan dua cara, pertama dengan membandingkan besarnya angka $F$ penelitian dengan $\mathrm{F}$ tabel, cara kedua dengan cara membandingkan angka taraf signifikan (sig) hasil perhitungan dengan taraf signifikansi 0,05 (Sarwono dan Ely, 2010).

\section{HASIL DAN PEMBAHASAN}

\subsection{Strategi Bauran Pemasaran Jasa (3P)}

Strategi bauran pemasaran jasa yang terdiri dari People (orang), Physical Evidence (Bukti fisik), dan Process (Proses) yang dilakukan oleh STIM Sukma agar kepuasan konsumen dalam hal ini mahasiswa tercapai serta keberlanjutan pemasaran jasa pendidikan dapat terwujud. Berikut adalah strategi bauran pemasaran jasa (3P) yang dikembangkan manajemen STIM Sukma Medan:

1. People (Orang)
Secara umum kinerja variabel orang dari bauran pemasaran STIM Sukma Medan berjalan baik, namun masih perlu perbaikan beberapa faktor yang berhubungan dengan orang, seperti perlu ditambahnya skill (keterampilan) dan pengetahuan staf pegawai sehingga lebih maksimal melayani mahasiswa dan perlunya ditegaskan kedisiplinan jam masuk dosen agar para dosen lebih tepat waktu ketika masuk kelas untuk mengajar.

2. Physical Evidence (Bukti fisik)

Dari data tanggapan responden tersebut menggambarkan bahwa secara umum kondisi bukti fisik STIM Sukam Medan yang telah ada belum memadai, masih perlu dilengkapi dan perlu perbaikan agar berfungsi dengan baik untuk menunjang kegiatan belajar mengajar mahasiswa. Untuk itu pihak STIM Sukam Medan perlu melengkapi sarana, prasarana ataupun fasilitas kampus sehingga kebutuhan belajar mengajar mahasiswa dapat terpenuhi secara maksimal.

\section{Process (Proses)}

Secara umum dapat disimpulkan bahwa kinerja variabel proses pada bauran pemasaran adalah baik. Kondisi ini sebaiknya dipertahankan, namun tentunya masih ada beberapa kendala dalam faktor proses ini yang dihadapi staf/pegawai yang terlibat dalam faktor proses ini. Kesemuanya ini haruslah menjadi perhatian dan catatan penting bagi pihak STIM Sukma Medan.

\subsubsection{Pengaruh Strategi Bauran Pemasaran Jasa (3P) Secara Simultan Terhadap Keputusan Mahasiswa Memilih}

Dari hasil analisis hipotesis secara simultan (bersama-sama) pengaruh seluruh variabel bebas berupa bauran pemasaran jasa (3P) dengan variabel terikat adalah sangat signifikan (nyata).

\subsubsection{Keputusan Mahasiswa Memilih}

Secara umum mahasiswa senang dan bangga memilih STIM Sukma Medan sebagai tempat melanjutkan pendidikannya, namun tentunya pihak STIM Sukma Medan perlu 
membenahi beberapa faktor lain yang terkait dengan bauran pemasaran jasanya mengingat kehadiran para pesaing STIM Sukma Medan yang sangat ketat serta harus diantisipasinya penyataan mahasiswa yang menyatakan memiliki rasa ketertarikan dengan kampus lain selain STIM Sukma Medan. Semua ini harus menjadi perhatian dan catatan penting bagi pihak STIM Sukma Medan untuk memfasilitasinya agar STIM Sukma Medan memiliki reputasi yang lebih baik lagi secara internal dan eksternal.

\subsection{Pembahasan}

\subsubsection{Strategi Bauran Pemasaran Jasa (3P)}

1. Pengaruh variabel Orang (People) dengan Keputusan Mahasiswa Memilih STIM Sukma Medan.

Berdasarkan hasil pengolahan data dengan SPSS menyatakan bahwa variabel orang $\left(\mathrm{X}_{1}\right)$ dengan variabel keputusan mahasiswa memilih mempunyai hubungan positif yang tidak signifikan. Hal ini sesuai dengan hasil penelitian sesungguhnya. Jadi hasil uji statistik dalam penelitian ini terdapat hubungan positif yang tidak signifikan antara orang denagn keputusan mahasiswa memilih STIM Sukma Medan.

Sumadi Suryabrata (2003:41) me ngemukakan bahwa hasil penelitian hubungan antara satu variabel dengan variabel yang lain signifikan atau tidak signifikan meupakan suatu kemungkinan yang bisa terjadi. Maka dari hasil penelitian ini merupakan fakta bahwa kebijakan dari faktor orang saja tidak akan mendukung secara nyata terhadap peningkatan keputusan mahasiswa memilih. Berdasarkan fakta bahwa keberadaan orang dalam hal ini adalah sumber daya manusia yang tergabung sebagai pengelola antara lain pimpinan perguruan tinggi, ketua program studi, dosen, dengan latar belakang pendidikannya, pegawai yang berada di lingkungan STIM Sukma Medan memberikan perhatian dan layanan yang cukup namun dirasakan belum memuaskan mahasiswa. Ditinjau dari pernyataan responden terhadap variabel program studi, yang didalamya mencakup indikator orang yang di dalamnya meliputi : pimpinan perguruan tinggi memberikan perhatian kepada mahasiswa namun dirasakan belum cukup dan pada akhirnya dianggap belum memuaskan mahasiswa. Dengan ketua program studi, mahasiswa diperhatikan perkembangan akademisnya namun dirasakan masih kurang oleh mahasiswa.

Dengan para dosen sebagai tenaga pengajar, komunikasi dan interaksi berjalan dengan baik, baik itu di dalam maupun diluar kelas, namun perlu kiranya menjadi perhatian bagi pihak STIM Sukma Medan tentang kehadiran dosen di kelas, karena dari tanggapan responden diperoleh $37,6 \%$ yang menyatakan setuju jika dosen tidak tepat waktu masuk ke lokal. Dengan para pegawai STIM Sukma Medan masih perlu kiranya pihak manajemen STIM Sukma Medan untuk menambah skill ataupun keterampilan juga pengetahuan pegawai yang mendukung kinerja pegawai administrasi akademik dalam hal melayani kepentingan akademik mahasiswa karena responden mengganggap pegawai masih belum terampil dalam melayani keperluan mahasiswa.

2. Pengaruh Physical Evidence (Bukti Fisik) dengan Keputusan Mahasiswa Memilih STIM Sukma Medan.

Berdasarkan hasil pengolahan data dengan SPSS versi 21.0 menyatakan bahwa variabel bukti fisik $\left(\mathrm{X}_{2}\right)$ dengan variabel keputusan mahasiswa memilih mempunyai hubungan positif yang tidak signifikan.

Hasil penelitian ini sesungguhnya tidaklah menolak kebenaran teori atau hipotesis sebelumnya. Karena dalam suatu penelitian, uji statistik bisa terjadi dua kemungkinan yaitu 1. hubungan variabelvariabel penelitian yang diteliti sangat signifikan, 2. hubungan variabel-variabel penelitian yang diteliti tidak signifikan (Narbuko dan Achmadi, 2012:66). Jadi hubungan antara variabel bukti fisik dengan 
variabel keputusan mahasiswa memilih STIM Sukma Medan yang tidak signifikan bukan karena kesalahan pada landasan teori, pengambilan sampel, perhitungan-perhitungan ataupun alat pengambil data yang dilakukan serta hasilnya semuanya sudah memenuhi standar dari suatu penelitian dan hasilnya terdapat hubungan positif yang tidak signifikan. Maka hasil penelitian ini merupakan fakta bahwa meningkatkan variabel bukti fisik (fasilitas) saja tidak akan mendukung secara nyata terhadap peningkatan keputusan mahasiswa dalam memilih STIM Sukma Medan, karena karena besaran kontribusi variabel bukti fisik terhadap keputusan memilih mahasiswa berdasarkan analisis regresi hanya $2,40 \%$.

3. Pengaruh Proses dengan Keputusan Mahasiswa Memilih STIM Sukma Medan.

Dari hasil pengolahan data dapat dijelasan bahwa koefisien regresi variabel proses tanda positif, kondisi ini menunjukkan bahwa pengaruh variabel proses searah terhadap keputusan mahasiswa dalam memilih STIM Sukma Medan, artinya bila variabel proses yang berupa semua prosedur aktual, mekanisme dan aliran akivitas dimana jasa disampaikan atau operasi sudah sesuai dan semakin baik maka akan berpengaruh kepada meningkatnya keputusan mahasiswa memilih STIM Sukma Medan sebagai tempat melanjutkan pendidikannya. Perolehan pengaruh proses sesuai yang dikemukakan oleh Payne (2000:210) bahwa proses menciptakan dan memberikan jasa pada pelanggan merupakan faktor utama dalam bauran pemasaran, karena pelanggan jasa akan memandang sistem pemberian jasa tersebut sebagai bagian dari jasa itu sendiri. Semua kegiatan pekerjaan adalah merupakan proses.

\subsubsection{Pengaruh Strategi Bauran Pemasaran} Jasa (3P) Secara Simultan Terhadap Keputusan Mahasiswa Memilih

Pengaruh orang, Bukti fisik dan Proses Terhadap Keputusan Mahasiswa Memilih
STIM Sukma Medan. Hasil pengolahan data dengan bantuan SPSS versi 21.0 menunjukkan bahwa secara simultan/bersama-sama variabel Orang, Bukti fisik dan Proses memiliki pengaruh yang positif dan signifikan terhadap keputusan mahasiswa memilih STIM Sukma Medan. Keputusan memilih mahasiswa meningkat jika semua yang termasuk dalam indikatornya dapat dilaksanakan oleh pihak manajemen STIM Sukma Medan secara maksimal.

\subsubsection{Keputusan Mahasiswa Memilih}

Berdasarkan hasil penelitian, bahwa semua indikator keputusan mahasiswa memilih meliputi : inisiatif kebutuhan, pencarian informasi, mengevaluasi informasi, ketepatan dalam memutuskan dan dampak psikologi setelah memutuskan dapat terlaksana oleh mahasiswa namun belum maksimal.

Hasil dari penelitian ini juga mengandung arti bahwa untuk meningkatkan keputusan mahasiswa yang lebih baik dan maksimal tidak hanya bisa mengandalkan satu kekuatan dari satu variabel saja tetapi pihak manajemen STIM Sukma Medan harus memberi perhatian yang sama pada semua variabel bauran pemasaran jasa yang mempengaruhi keputusan mahasiswa memilih STIM Sukma Medan. Makna highly significant menunjukkan bahwa orang, bukti fisik dan proses berpengaruh sangat signifikan (sangat nyata) terhadap keputusan mahasiswa memilih STIM Sukma Medan.

\section{KESIMPULAN DAN SARAN}

\subsection{Kesimpulan}

Berdasarkan hasil penelitian dan pembahsan pada bab sebelumnya, maka dapat ditarik kesimpulan sebagai berikut :

1. Terdapat pengaruh yang tidak signifikan (tidak nyata) antara orang terhadap keputusan mahasiswa memilih STIM Sukma Medan.

2. Terdapat pengaruh yang tidak signifikan (tidak nyata) antara bukti fisik terhadap 
keputusan mahasiswa memilih STIM Sukma Medan.

3. Terdapat pengaruh yang signifikan (nyata) antara proses terhadap keputusan mahasiswa memilih STIM Sukma Medan.

4. Terdapat pengaruh yang sangat signifikan (nyata) secara simultan atau bersama-sama antara orang (people), bukti fisik (physical evidence) dan proses (process) terhadap keputusan mahasiswa memilih STIM Sukma Medan.

\subsection{Saran}

Dari kesimpulan yang telah diuraikan diatas, maka peneliti dapat memberikan saransaran sebagai berikut :

1. Terhadap faktor orang (people), sebaiknya pihak STIM Sukma tetap mempertahankan kondisi yang sudah terjalin dengan baik antara mahasiswa dengan pihak manajemen STIM Sukma Medan beserta jajarannya. Seperti hubungan ketua STIM Sukma Medan dengan mahasiswa yang terlihat bersahabat dan kekeluargaan, demikian pula kondisi dan komunikasi yang sudah tercipta dengan baik antara ketua program studi dengan mahasisa maupun para dosen dengan mahasiswa. Kondisi yang sudah tercipta baik ini diharapkan mampu menjadi kontribusi besar terhadap keputusan mahasiswa memilih STIM Sukma Medan sebagai tempatnya melanjutkan pendidikan. Namun perlu menjadi catatan pula agar kiranya terus meningkatkan keilmuan staf pengajarnya dan mengadakan pelatihan/keterampilan bagi segenap staf pegawainya.

2. Pada bukti fisik ((physical evidence) dengan penambahan fasilitas ataupun sarana dan prasarana misalnya menambah koleksi buku-buku di perpustakaan, memperbesar ruangannya, menambah luas areal gedung kampus karena lokasi kampus terkesan sempit hingga kondisi ini membuat terhambatnya ruang gerak dan aktivitas mahasiswa terlihat kendala ruangan selama ini sering terjadi, tentunya ini menjadi catatan penting bagi pihak pengelola STIM Sukma Medan dalam upaya peningkatan keputusan mahasiswa dalam memilih STIM Sukma Medan sebagai tempat melanjutkan pendidikan.

3. Terhadap faktor proses (process), standar prosedur perguruan tinggi yang sesuai sudah diikuti dan dijalani oleh STIM Sukma Medan mulai dari prosedur penerimaan mahasiswa baru sampai dengan proses daftar ulang untuk menjadi mahasiswa dan melaksanakan proses belajar mengajar yang mengikuti jadwal kalender akademik, sebaiknya kondisi yang sudah tercipta baik ini dipertahankan, namun tetap perlu ada peningkatan keterampilan / skill dari pegawai/staf dalam proses melayani kepentingan akademik mahasiswa.

4. Dalam upaya meningkatkan keputusan mahasiswa untuk memilih STIM Sukma Medan sebagai tempat mahasiswa melanjutkan studinya, hendaknya yang harus menjadi pertimbangan strategis pihak Sekolah Tinggi Ilmu Manajemen (STIM) Sukma Medan adalah faktor bauran pemasaran jasa (3P) yang terdiri dari : orang, bukti fisik dan proses. Berarti ketiga bauran pemasaran jasa perlu menjadi perhatian yang strategis dalam membuat kebijakan pemasarannya, tidak bisa hanya meningkatkan satu faktor/variabel saja dari bauran pemasaran jasa (3P) untuk meningkatkan keputusan mahasiswa dalam memilih STIM Sukma Medan sebagai Perguruan tinggi tempat melanjutkan pendidikan. 


\section{DAFTAR PUSTAKA}

[1] Adrian, Payne, (2000), Pemasaran Jasa, The Essence of Service Marketing, Andi Yogyakarta.

[2] Alma Buchari (2007), Manajemen Bisnis (Berbasis Hasil Penelitian), Alfabeta, Bandung.

[3] Hidayat, Azis Alimul (2008), Metode Penelitian Dan Teknik Analisis Data, Salemba Medika, Jakarta.

[4] Hurriyati, Ratih (2009), Manajemen Corporate \& Strategi Pemasaran Jasa Pendidikan Fokus Mutu dan Pelayanan Prima, Bandung: Alfabeta.

[5] Lupiyoadi, Rambat dan A. Hamdani, (2008). Manajemen Pemasaran Jasa, Jakarta: Salemba Empat.

[6]

(2009), Manajemen Pemasaran Jasa, Edisi Kedua, Jakarta: Salemba Empat.

[7] Margaretha dan Nilo. (2016). Analisis Pemilihan PTS di Jakarta dengan Fishbein dan Biplot. Pengesahan Proposal Innovation Award 2016. Bina Nusantara.

[8] Sarwono, J. Dan S. Ely (2010). Riset Akuntansi Menggunakan SPSS. Yogyakarta: Graha Ilmu.

[9] Suharsini, Arikunto. (2009). Prosedur Penelitian Suatu Pendekatan Praktik. Edisi Revisi. Cetakan kesebelas. Jakarta: Rineka Cipta.

[10] Suryabrata, Sumadi (2003), Metodologi Penelitian, PT Raja Grafindo Persada, Jakarta.

[11] Wijaya, D. (2012), Pemasaran Jasa Pendidikan, Jakarta: Salemba Empat.

[12] Yazid. (2008). Pemasaran Jasa: Konsep dan Implementasi. Edisi Pertama, Yogyakarta: Ekonisia Fakultas Ekonomi.

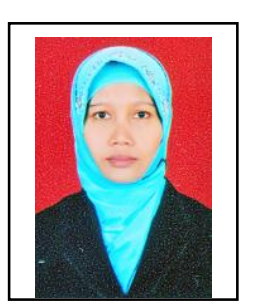

Yuni Asri Ningratri, lahir di Medan, tanggal 10 Juni 19977 jenis kelamin perempuan. Memperoleh gelar Sarjana Ekonomi (SE) bidang Manajemen dari Universitas Sumatera Utara (USU) Medan dan memperoleh gelar (MM) dari Universitas Muhammadiyah Sumatera Utara (UMSU) Program studi Ekonomi Manajemen jenjang Strata 2 (S2) Magister Manajemen. Bekerja sebagai Dosen tetap pada STIM Sukma Medan. 